\title{
Pengaruh Pemberian Pupuk Organik Cair Komersial Biofarm dengan Pembanding Ab- Mix pada Budidaya Sawi Pakcoy (Brassica rapa subsp chinensis) secara Hidroponik Teknik Rakit Apung
}

Cut Theresia Candra Lakshitowati ${ }^{1 *}$, Djoko Murdono ${ }^{1}$

${ }^{1}$ Departemen Agroteknologi, Fakultas Pertanian dan Bisnis, Universitas Kristen Satya Wacana

\begin{tabular}{l}
\multicolumn{1}{c}{ ARTIKEL INFO } \\
\hline Sejarah artikel \\
Diterima $18 / 03 / 2021$ \\
Diterima dalam bentuk revisi $07 / 04 / 2021$ \\
Diterima dan disetujui 21/04/2021 \\
Tersedia online 22/06/2021 \\
\hline Kata kunci \\
Hidroponik \\
Nutrisi \\
Pakcoy \\
Pertumbuhan \\
Pupuk organik cair \\
\hline
\end{tabular}

\begin{abstract}
ABSTRAK
Pupuk organik cair komersial dapat digunakan sebagai pupuk alternatif bagi tanaman sayuran pakcoy yang dibudidayakan secara hidroponik teknik rakit apung, namun informasi tentang konsentrasi pupuk organik cair tersebut perlu diteliti supaya diperoleh pertumbuhan dan hasil tanaman yang maksimal. Penelitian ini bertujuan untuk menentukan konsentrasi pupuk organik cair tersebut yang mampu menghasilkan pertumbuhan dan hasil setara dengan AB-mix pada tanaman pakcoy yang ditanam secara hidroponik teknik rakit apung. Lokasi penelitian beralamatkan di Jalan Aliwijayan II RT 04 RW 03, Kelurahan Mangunsari, Kecamatan Sidomukti, Kota Salatiga, Jawa Tengah, pada bulan Agustus 2020 - September 2020. Penelitian dilakukan di dalam greenhouse, menggunakan Rancangan Acak Kelompok (RAK) dengan 6 perlakuan dan diulang 4 kali. Perlakuan yang di uji yaitu AB-mix sebagai pembanding, pupuk organik cair komersial biofarm $2 \mathrm{ml} / \mathrm{l}, 4 \mathrm{ml} / \mathrm{l}, 6 \mathrm{ml} / \mathrm{l}, 8$ $\mathrm{ml} / \mathrm{l}, \quad 10 \mathrm{ml} / \mathrm{l})$. Parameter pengamatan meliputi tinggi tanaman, jumlah daun, luas daun, diameter bonggol, bobot segar tajuk, dan bobot kering tajuk. Hasil pengamatan dianalisis menggunakan aplikasi SAS untuk melihat sidik ragam (uji F 5\%), dan dilanjutkan dengan uji Duncan Multiple Range Test selang kepercayaan 95\%. Hasil penelitian menunjukkan bahwa semua perlakuan konsentrasi pupuk organik cair tersebut belum mampu menghasilkan setara dengan pertumbuhan dan hasil tanaman Pakcoy yang ditumbuhkan pada nutrisi AB-mix.
\end{abstract}

(C) 2021 Politeknik Pembangunan Pertanian Manokwari 


\section{ABSTRACT}

Commercial liquid organic fertilizer can be used as an alternative fertilizer for vegetable plants Pakcoy cultivated hydroponics floating raft techniques, but information about the concentration of liquid organic fertilizer needs to be researched in order to obtain maximum growth and crop yield. This study aims to determine the concentration of liquid organic fertilizer that is able to produce growth and yields equivalent to $A B$-mix in Pakcoy plants that are planted hydroponics floating raft techniques. The research location is located at Aliwijayan II RT 04 RW 03 Mangunsari Subdistrict, Sidomukti Subdistrict, Salatiga City, Central Java, in August 2020 - September 2020. The research was conducted in a greenhouse, using a Randomized

\section{PENDAHULUAN}

Hidroponik merupakan budidaya tanaman tanpa menggunakan media tanah, melainkan menggunakan air yang mengandung larutan nutrisi sebagai media tumbuh, sehingga sistem bercocok tanam ini dapat dilakukan ditempat sempit (Roidah, 2014). Sistem hidroponik terbagi menjadi beberapa teknik salah satunya rakit apung, teknik ini menggunakan styrofoam yang dilubangi sebagai tempat tanaman berdiri, kemudian styrofoam diapungkan ke dalam bak yang berisi larutan nutrisi supaya akar tanaman terendam dan dapat menyerap nutrisi. Tanaman yang sering dibudidayakan menggunakan teknik ini yaitu tanaman sayuran (Suhardiyanto, 2010). Sayuran sawi Pakcoy (Brassica rapa subsp chinensis) salah satu sayuran daun yang memiliki nilai ekonomi tinggi, tanaman Pakcoy sendiri dapat tumbuh di dataran tinggi maupun dataran rendah (Sarido \& Junia, 2017a). Tanaman hidroponik dapat menghasilkan panenan yang maksimal apabila di berikan nutrisi yang dapat mencukupi kebutuhan pertumbuhan tanaman. Nutrisi dalam budidaya tanaman secara hidroponik sendiri merupakan
Block Design (RBD) with 6 treatments and repeated 4 times. The treatment tested is AB-mix as a comparison, commercial liquid organic fertilizer biofarm $2 \mathrm{ml} / \mathrm{l}, 4 \mathrm{ml} / \mathrm{l}, 6 \mathrm{ml} / \mathrm{l}, 8 \mathrm{ml} / \mathrm{l}, 10 \mathrm{ml} /$ l).Observation parameters include plant height, number of leaves, leaf area, weevil diameter, fresh header weight, and header dry weight. The observations were analyzed using SAS applications to see fingerprints ( $F$ test $5 \%$ ), and continued with the Duncan Multiple Range Test $95 \%$ confidence hose test. The results showed that all treatment concentrations of liquid organic fertilizer has not been able to produce equivalent to the growth and yield of Pakcoy plants grown in AB-mix nutrients.

campuran garam - garam pupuk makro dan mikro yang dilarutkan dan diberi secara teratur (Lingga, 1989).

Nutrisi yang lazim digunakan dalam hidroponik adalah pupuk kimia sintesis ABmix yang mudah didapatkan di pasaran. Mulai banyaknya budidaya sayuran menggunakan sistem hidroponik membuat semakin banyak pula petani yang akan mengunakan pupuk kimia sintetis, akibatkannya dapat berdampak buruk bagi lingkungan. Oleh sebab itu penelitian ini mencoba menggunakan pupuk organik cair ramah lingkungan yang dijual dipasaran, yang sebeneranya berpotensi untuk dijadikan nutrisi hidroponik. Pupuk organik cair (POC) Biofarm terbuat dari bahan - bahan organik hasil sampingan dari produksi jamu yang berbahan baku tanaman obat dan rempah - rempah. POC ini mengandung 3,20\% $\mathrm{N}$, $3,63 \% \mathrm{P}_{2} \mathrm{O}_{5}, 3,55 \% \mathrm{~K}_{2} \mathrm{O}, 0,0199 \% \mathrm{Fe}, 0,0317 \%$ $\mathrm{Mn} \mathrm{,} \mathrm{0,0251 \%} \mathrm{Cu,} \mathrm{0,0254 \%} \mathrm{Zn,} \mathrm{0,0768 \%} \mathrm{B,}$ 0,0005\% Co, $0,0002 \%$ Mo (PT Sido muncul pupuk nusantara, 2015).

Berdasarkan latar belakang di atas, perlu dilakukan penelitian pemberian berbagai macam konsentrasi POC Biofarm sebagai 
nutrisi hidroponik rakit apung pada tanaman Pakcoy dengan pembandingnya adalah ABmix. Penelitian ini bertujuan menentukan konsentrasi POC Biofarm yang mampu menghasilkan pertumbuhan dan hasil setara dengan AB-mix pada tanaman Pakcoy yang ditanam secara hidroponik rakit apung.

\section{METODE}

Penelitian ini dilaksanakan di greenhouse mengalamatkan di Jalan Aliwijaya II RT 04 RW 03, Kelurahan Mangunsari, Kecamatan Sidomukti, Kota Salatiga, Jawa Tengah. Penelitian telah dilaksanakan pada bulan Agustus 2020 hingga September 2020. Alat yang digunakan dalam penelitian ini yaitu, bak plastik berukuran $43 \mathrm{~cm}$ x $33 \mathrm{~cm}$ x $16 \mathrm{~cm}$, pH meter, EC meter, aerator, selang aerator, gelas ukur, sendok pengaduk pupuk, penggaris, jangka sorong, timbangan digital. Bahan yang digunakan dalam penelitian yaitu benih sawi Pakcoy varietas Green, pupuk AB-mix, pupuk organik cair Biofarm, rockwool, styrofoam, air, net pot.

Penelitian menggunakan rancangan acak kelompok (RAK). Terdapat 6 perlakuan pemberian pupuk, yaitu pupuk komersial $\mathrm{AB}$ $\operatorname{mix}(5+5) \mathrm{ml} / \mathrm{l}$, POC Biofarm $2 \mathrm{ml} / \mathrm{l}, 4 \mathrm{ml} / \mathrm{l}, 6$ $\mathrm{ml} / \mathrm{l}, 8 \mathrm{ml} / \mathrm{l}, 10 \mathrm{ml} / \mathrm{l}$. Perlakuan tersebut diulang 4 kali.

Pelaksanaan metode rakit apung dilakukan dengan menyiapkan bak tanam sebanyak 24 buah, dengan ukuran $43 \mathrm{~cm}$ x 33 $\mathrm{cm}$ x $16 \mathrm{~cm}$. Styrofoam tebal $3 \mathrm{~cm}$ dibentuk persegi dengan ukuran $41 \mathrm{~cm}$ x $32 \mathrm{~cm}$, lubang tanam sebanyak 4 dengan jarak tanam $20 \mathrm{~cm} \mathrm{x}$ $20 \mathrm{~cm}$, disiapkan sebanyak 24 buah. Benih sawi Pakcoy disemai dengan media rockwool berbentuk kubus berukuran $2 \mathrm{~cm}$ x $2 \mathrm{~cm}$ selama 12 hari, dengan ketentuan dalam satu kubus rockwool hanya terdapat satu benih sawi Pakcoy. Tanaman yang sudah berumur 12 hari setelah semai dipindah ke hidroponik rakit apung dengan menaruh rockwool yang berisi bibit ke dalam net pot. Pemberian pupuk sesuai dengan konsentrasi yang sudah masing - masing perlakuan. Setiap pupuk dimasukkan ke dalam bak yang berisi air dengan volume 18 liter/ bak. Parameter yang diamati dalam pelaksanaan ini adalah tinggi tanaman dan jumlah daun, luas daun, diameter bonggol, bobot segar tajuk dan bobot kering tajuk yang mulai dilakukan pengamatan setelah panen dilakukan. Data dianalisis dengan metode sidik ragam (uji F 5\%) kemudian dilanjutkan dengan uji Duncan's Multiple Range Test (DMRT) dengan selang kepercayaan 95\%. Aplikasi Statistical Analysis Softwere (SAS) digunakan sebagai alat bantu analisis data.

\section{HASIL DAN PEMBAHASAN}

\section{Pertumbuhan Tanaman}

Pertumbuhan tanaman sawi Pakcoy yang diberi perlakuan pupuk organik cair biofarm dan pupuk pembanding $\mathrm{AB}$-mix, menghasilkan pengaruh nyata dalam uji DMRT 5\% terhadap parameter pengamatan seperti tinggi tanaman, luas daun, jumlah daun, dan diameter bonggol. Rekapitulasi data rata - rata pertumbuhan ditampilkan pada Tabel 1.

Berdasarkan data Tabel 1 dapat terlihat bahwa pada semua parameter pertumbuhan, perlakuan pupuk pembanding AB-mix menunjukkan hasil yang nyata lebih baik dibanding dengan semua perlakuan pupuk 
organik cair (POC) Biofarm. Budidaya menggunakan sistem hidroponik biasanya dilakukan dua kegiatan ini untuk memastikan nutrisi yang diberikan dapat terserap oleh tanaman dengan baik yaitu pengukuran EC (Electrical Condictivity) dan $\mathrm{pH}$ (Power of Hydrogen). Dalam penelitian ini EC yang diamati satu hari dua kali menunjukkan nilai yang baik untuk pertumbuhan tanaman sawi pakcoy yaitu 1,5-2,0 $\mathrm{mS} / \mathrm{cm}$, sedangkan untuk nilai pH larutan nutrisi perlakuan POC Biofarm mengalami kenaikan yang sangat signifikan. Hal ini diduga yang menyebabkan hasil dari perlakuan POC Biofarm menjadi berbeda dengan perlakuan pupuk pembanding $\mathrm{AB}$-mix.
Power of Hydrogen $(\mathrm{pH})$ merupakan parameter pengukur keasaman dan alkalinitas suatu larutan yang digunakan untuk melihat ketersediaan nutrisi bagi tanaman. $\mathrm{pH}$ menunjukkan hubungan antara konsentrasi ion bebas hidrogen $(\mathrm{H}+)$ dan hidroksida $(\mathrm{OH}-)$ yang terdapat dalam larutan (Trejo \& Gomez, 2014). Skala $\mathrm{pH}$ berkisar dari $0-14$, nilai $\mathrm{pH} 7$ merupakan nilai netral yang ideal untuk berbudidaya tanaman. Nilai $\mathrm{pH}$ dibawah 7 menunjukkan keasaman dan nilai di atas 7 menunjukkan basa, namun rentang $\mathrm{pH}$ ideal untuk setiap tanaman berbeda - beda (Iqbal, 2016).

Tabel 1 Rekapitulasi data rata - rata pertumbuhan tanaman Pakcoy

\begin{tabular}{lcccc}
\hline $\begin{array}{c}\text { Perlakuan } \\
(\mathrm{ml} / \mathrm{l})\end{array}$ & $\begin{array}{c}\text { Tinggi Tanaman } \\
(\mathrm{cm})\end{array}$ & $\begin{array}{c}\text { Luas Daun } \\
\left(\mathrm{cm}^{2}\right)\end{array}$ & $\begin{array}{c}\text { Jumlah Daun } \\
(\text { helai })\end{array}$ & $\begin{array}{c}\text { Diameter Bonggol } \\
(\mathrm{cm})\end{array}$ \\
\hline AB-mix & $32,44 \mathrm{a}$ & $3040 \mathrm{a}$ & $23,81 \mathrm{a}$ & $7,43 \mathrm{a}$ \\
POC $2 \mathrm{ml} / \mathrm{l}$ & $24,25 \mathrm{c}$ & $947 \mathrm{~b}$ & $14,69 \mathrm{~b}$ & $4,31 \mathrm{~b}$ \\
POC $4 \mathrm{ml} / 1$ & $25,31 \mathrm{bc}$ & $1182 \mathrm{~b}$ & $15,31 \mathrm{~b}$ & $4,71 \mathrm{~b}$ \\
POC $6 \mathrm{ml} / 1$ & $28,00 \mathrm{~b}$ & $1541 \mathrm{~b}$ & $16,69 \mathrm{~b}$ & $5,29 \mathrm{~b}$ \\
POC $8 \mathrm{ml} / 1$ & $26,81 \mathrm{bc}$ & $994 \mathrm{~b}$ & $15,63 \mathrm{~b}$ & $4,73 \mathrm{~b}$ \\
POC $10 \mathrm{ml} / 1$ & $26,15 \mathrm{bc}$ & $1443 \mathrm{~b}$ & $15,38 \mathrm{~b}$ & $5,23 \mathrm{~b}$ \\
\hline
\end{tabular}

Keterangan: Angka yang diikuti notasi huruf yang sama pada kolom yang sama, tidak berbeda nyata antara perlakuan pada uji DMRT 5\%

Nilai pH larutan nutrisi hidroponik agar mendapatkan hasil yang baik untuk tanaman sawi pakcoy direkomendasikan dengan nilai $\mathrm{pH}$ yaitu 5,5 - 6,5. Besarnya nilai $\mathrm{pH}$ sangatlah berpengaruh pada penyerapan akar terhadap unsur hara yang terkandung dalam nutrisi, sehingga jika $\mathrm{pH}$ menunjukkan nilai yang terlalu rendah atau tinggi akan menyebabkan akar tidak dapat menyerap unsur hara dengan optimal sehingga tanaman mengalami defisiensi (Swastika et al., 2018). Berdasarkan pengamatan $\mathrm{pH}$ larutan nutrisi yang dilakukan dari 12 HST - 43 HST pada setiap perlakuan didapatkan hasil, nilai $\mathrm{pH}$ perlakuan pupuk pembanding $\mathrm{AB}$-mix meningkat seiring bertambahnya umur tanaman, namun kenaikan ini tidak terjadi signifikan seperti yang ditunjukkan pada Lampiran 1. Kenaikan ini diakibatkan tanaman yang mulai bertambah besar ukurannya akan menyerap kation seperti nitrat dengan jumlah yang lebih banyak. Penyerapan ini membuat tanaman mengeluarkan OH- atau HCO3-, untuk menyeimbangkan muatan listrik di dalamnya yang menghasilkan peningkatan nilai $\mathrm{pH}$ 
(Marschner, 1985). Perlakuan POC Biofarm pada umur 13 HST sudah mengalami kenaikan sangat signifikan dan terus mengalami kenaikan sampai 43 HST. Kenaikan pH larutan nutrisi yang sangat signifikan pada semua perlakuan POC Biofarm diakibatkan tidak adanya buffer yang berfungsi sebagai penyangga agar nilai $\mathrm{pH}$ larutan nutrisi tidak naik atau turun secara signifikan, dan air baku yang memiliki nilai $\mathrm{pH}$ mencapai 8,0 (basa). Menurut Iqbal (2016) perubahan nilai $\mathrm{pH}$ yang signifikan pada larutan nutrisi jarang terjadi, nilai $\mathrm{pH}$ yang tidak ideal hanya terjadi bila air baku berasal dari daerah yang memiliki $\mathrm{pH}$ air tanah yang tidak ideal seperti perbukitan kapur, rawa, pasang surut atau tanah gambut. Namun meskipun nilai $\mathrm{pH}$ air baku tinggi namun hal ini tidak berpengaruh pada $\mathrm{pH}$ perlakuan pupuk pembanding $\mathrm{AB}$-mix hal ini diduga AB-mix memiliki buffer (larutan penyangga) yang berfungsi menjaga kestabilan $\mathrm{pH}$, sehingga $\mathrm{pH}$ larutan nutrisi tidak mengalami penurunan atau kenaikan nilai $\mathrm{pH}$ secara signifikan.

Pengaruh $\mathrm{pH}$ yang tinggi melebihi standar $\mathrm{pH}$ 5,5- 6,5 mengakibatkan tanaman kekurangan unsur hara tersedia yang berguna untuk masa pertumbuhan seperti unsur hara $\mathrm{N}$, $\mathrm{P}, \mathrm{K}$, akibatnya pertumbuhan vegetatif tanaman terganggu. Kekurangan unsur hara nitrogen $(\mathrm{N})$ dan fosfor $(\mathrm{P})$ oleh tanaman yang diberikan perlakuan POC Biofarm mengakibatkan terhambatnya pertumbuhan tinggi tanaman, jumlah daun, dan luas daun. Dapat dilihat pada Tabel 1 bahwa tanaman POC Biofarm tidak mampu menyamai hasil dari AB-mix. Budi \& Sari (2015) mengatakan bahwa kekurangan nitrogen dan fosfat akan membuat tanaman kerdil yang disebabkan oleh terhambatnya pembelahan sel. Daun tua mulai berwarna pucat dikarenakan terhambatnya pembentukan klorofil membuat tanaman tidak banyak membentuk karbohidrat yang nantinya akan diubah ke dalam bentuk protein digunakan untuk pembentukan sel - sel baru yang dapat menambah tinggi, jumlah daun dan luas daun tanaman. Luas daun tanaman yang rendah akan mempengaruhi tanaman untuk memproduksi karbohidrat, menurut Sarido \& Junia (2017) semakin luas suatu daun maka semakin banyak proses fotosintesis di dalamnya dan akan menghasilkan fotosintat lebih banyak untuk energi pembuatan organ tanaman. Selain itu rendahnya unsur hara $\mathrm{P}$ dalam tanaman akan mudah terserang penyakit yang mengakibatkan daun tanaman rusak, akar tanaman mudah terserang penyakit yang mengakibatkan kebusukan, yang akhirnya membuat tanaman tidak mampu melakukan proses fotosintesis dan penyerapan nutrisi secara optimal.

Selain pertumbuhan tanaman Pakcoy dipengaruhi oleh unsur hara nitrogen dan fosfor, unsur hara kalium (K) juga tidak kalah mempengaruhi masa pertumbuhan tanaman. Dalam pertumbuhan tanaman Pakcoy yang diberi perlakuan POC Biofarm cukup terlihat jelas bahwa tanaman juga kekurangan unsur K, dimana tanaman yang kekurangan unsur ini akan terhambat pertumbuhannya dikarenakan sel tanaman tidak dapat tumbuh dengan optimal, menurut Rosmarkam \& Yuwono (2002) bahwa kekurangan unsur hara $\mathrm{K}$ akan mengakibatkan kumulasi karbohidrat, dan akumulasi senyawa nitrogen dalam tanaman. Hal ini diakibatkan dari kegiatan enzim yang 
terhambat, sehingga terjadi penimbunan senyawa tertentu. Terhambatnya kegiatan enzim dapat menyebabkan terganggunya pembentukan protein yang mengakibatkan pembelahan sel terganggu sehingga pembentukan organ baru seperti batang dan daun tidak optimal. Pengaruh kekurangan unsur hara $\mathrm{K}$ pada daun yaitu dapat menyebabkan daun tanaman kering, ujung daun berwarna coklat atau noda coklat (nekrosis), jika kekurangan unsur hara ini berlangsung terus maka nekrosis ini akan menjadi jaringan mati dan kemudian akan lepas dari daun yang menyebabkan daun berlubang atau rusak. Seperti yang dapat dilihat dari Gambar 1 di mana tanaman yang diberi perlakuan POC Biofarm terdapat daun yang mengalami nikrosis pada ujung daun kemudian daun menjadi kering, selain itu kering pada ujung daun juga menyerang daun baru yang mengakibatkan daun kerdil dan mengganggu luas daun dimana luas daun berpengaruh pada proses fotosintesis.

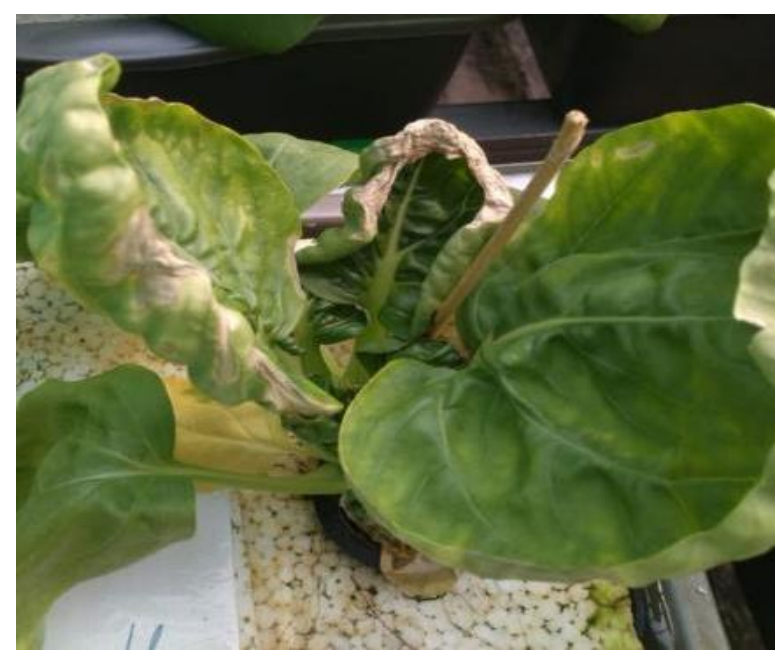

Gambar 1. Daun Tanaman Kering yang Diberi Perlakuan POC

Ukuran diameter bonggol dipengaruhi oleh tinggi tanaman dan jumlah daun, di mana jika tanaman tinggi maka semakin banyak ruas pada batang yang dapat ditumbuhi tangkai daun, dan jika tanaman tangkai daun banyak maka banyak juga jumlah daun yang dimiliki tanaman tersebut. Dapat dilihat pada Gambar 2 bahwa terlihat jelas ukuran bonggol dari tanaman yang diberi perlakuan AB-mix (kiri) dan diberikan perlakuan POC Biofarm 6 ml/l air (kanan). Rendahnya unsur hara yang terserap tanaman diakibatkan oleh $\mathrm{pH}$ yang terlalu tinggi pada perlakuan POC Biofarm berdampak pada pertumbuhan tanaman, sehingga berpengaruh juga pada diameter bonggol dapat dilihat pada Tabel 1 bahwa perlakuan pembanding AB-mix yang memiliki nilai tinggi pada pengamatan tinggi tanaman, jumlah daun maka diameter bonggolnya juga tinggi. Selaras dengan penelitian Rizal (2017) nutrisi yang sesuai dengan kebutuhan tanaman akan mendukung terjadinya pertumbuhan tanaman secara optimal yang membuat proses pembelahan, pembesaran dan pemanjangan sel terjadi dengan cepat sehingga organ tanaman akan tumbuh dengan cepat dan optimal.

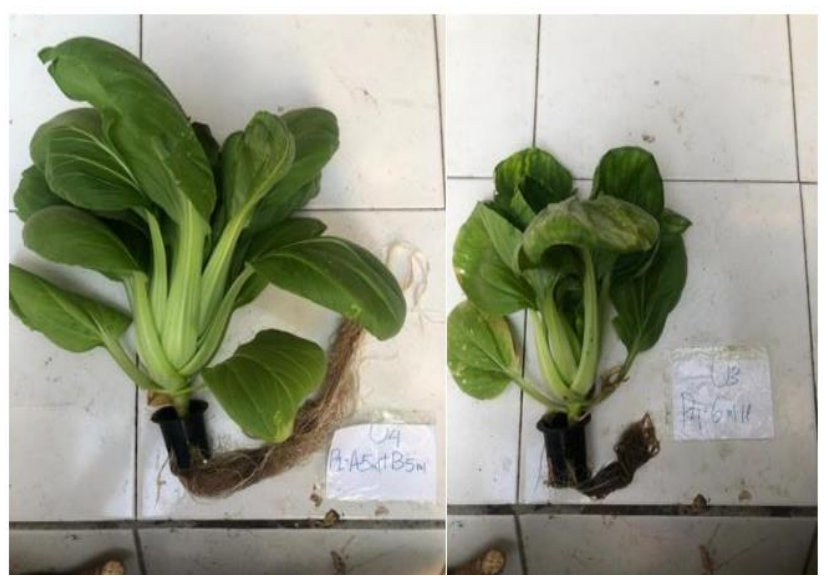

Gambar 2. Tanaman Perlakuan AB-mix (kiri) dan Perlakuan POC 6 ml/l (kanan) 


\section{Hasil Tanaman Pakcoy}

Hasil tanaman sawi Pakcoy yang diberi perlakuan pupuk organik cair Biofarm dan pupuk pembanding AB-mix, menghasilkan pengaruh berbeda nyata dalam uji DMRT 5\% terhadap parameter pengamatan bobot basah tajuk dan bobot kering tajuk. Rekapitulasi data rata - rata hasil dapat dilihat pada Tabel 2.

Tabel 2. Rekapitulasi Data Rata - Rata Hasil Tanaman Pakcoy

\begin{tabular}{lcc}
\hline $\begin{array}{c}\text { Perlakuan } \\
(\mathbf{m l} / \mathrm{l})\end{array}$ & $\begin{array}{c}\text { Bobot } \\
\text { Basah } \\
\text { Tajuk } \\
\text { (gram) }\end{array}$ & $\begin{array}{c}\text { Bobot } \\
\text { Kering } \\
\text { Tajuk } \\
\text { (gram) }\end{array}$ \\
\hline AB-mix & $287,26 \mathrm{a}$ & $14,13 \mathrm{a}$ \\
POC $2 \mathrm{ml} / 1$ & $72,48 \mathrm{c}$ & $4,61 \mathrm{~b}$ \\
POC $4 \mathrm{ml} / 1$ & $87,50 \mathrm{bc}$ & $5,21 \mathrm{~b}$ \\
POC $6 \mathrm{ml} / 1$ & $130,95 \mathrm{~b}$ & $7,01 \mathrm{~b}$ \\
POC $8 \mathrm{ml} / 1$ & $88,97 \mathrm{bc}$ & $5,24 \mathrm{~b}$ \\
POC $10 \mathrm{ml} / 1$ & $112,61 \mathrm{bc}$ & $6,39 \mathrm{~b}$ \\
\hline
\end{tabular}

Keterangan: Angka yang diikuti notasi huruf yang sama pada kolom yang sama, tidak berbeda nyata antara perlakuan pada uji DMRT $5 \%$

Hasil bobot basah tajuk dan bobot kering tajuk pada Tabel 2 menunjukkan bahwa perlakuan pupuk pembanding $\mathrm{AB}$-mix berbeda nyata dengan semua perlakuan POC Biofarm. Pada parameter ini perlakuan pupuk pembanding AB-mix memiliki berat paling tinggi diantara semua perlakuan POC Biofarm. Selaras dengan penelitian Tama \& Suprihati (2020) bahwa jumlah daun akan mempengaruhi hasil nilai bobot basah tajuk tinggi atau rendah, dikarenakan pada tanaman sayur daun merupakan sink. Semakin banyak jumlah daun akan menyebabkan kadar air pada tanaman meningkat, sehingga bobot segar tajuk tanaman akan meningkat. Luas daun, diameter bonggol, tinggi tanaman juga memiliki pengaruh pada bobot basah segar, dikarenakan pada saat tanaman tinggi akan berpengaruh pada luas daun yang akan melebar dan daun - daun baru akan mulai tumbuh yang menyebabkan diameter bonggol bertambah, sehingga mempengaruhi bobot segar tajuk menjadi lebih tinggi.

Tingginya nilai hasil dari bobot basah tajuk juga akan berpengaruh pada bobot kering tajuk di mana berat dari bobot ini merupakan biomassa yang terbentuk dari proses pertumbuhan. Sehingga tidak optimalnya pertumbuhan tanaman yang diberi perlakuan POC Biofarm membuat berat dari bobot kering tajuk menjadi rendah. Selaras penelitian Siregar (2017) ukuran tanaman yang kerdil, daun tanaman yang sedikit, mengakibatkan sedikit pula pembentukan karbohidrat dari hasil asimilasi, hal ini yang akan berdampak pada berat basah tanaman serta berat kering tanaman.

\section{KESIMPULAN DAN SARAN}

Pemberian pupuk organik cair Biofarm dengan berbagai macam konsentrasi belum mampu setara dengan hasil perlakuan pupuk pembanding AB-mix dalam semua parameter yang di amati seperti tinggi tanaman, jumlah daun, luas daun, diameter bonggol, bobot segar tajuk, bobot kering tajuk.

Penelitian selanjutnya perlu adanya penambahan buffer $\mathrm{pH}$ pada POC Biofarm atau pupuk - pupuk organik cair lainnya agar bisa menyamai keragaan tanaman yang diberi pupuk AB-mix. 


\section{DAFTAR PUSTAKA}

Budi, S., \& Sari, S. (2015). Ilmu dan Implementasi Kesuburan Tanah. Universitas Muhamadiyah Malang.

Iqbal, M. (2016). Simpel Hidroponik (S. Suyantoro (ed.)). Liliy Publisher.

Lingga, P. (1989). Hidroponik Bercocok Tanam Tanpa Tanah. PT Penebar Swadaya.

Marschner, H. (1985). Mineral Nutrition of Higher Pla. In The Oxford Handbook of International Business (2 ed.). Academic Press.

PT Sido Muncul Pupuk Nusantara. (2015). BIOFARM.

Rizal, S. (2017). Pengaruh Nutrisi yang Diberikan terhadap Pertumbuhan Tanaman Sawi Pakcoy (Brassica rapa L.) yang Ditanam secara Hidroponik. Journal of Chemical Information and Modeling, 14.

Roidah, I. (2014). Pemanfaatan Lahan dengan Menggunakan Sistem Hidroponik. 1(2), 43-50.

Rosmarkam, A., \& Yuwono, N. (2002). Ilmu Kesuburan Tanah. PT Kanisius.

Sarido, L., \& Junia. (2017a). Uji Pertumbuhan dan Hasil Tanaman Pakcoy (Brassica rapa L.) dengan Pemberian Pupuk Organik Cair pada Sistem Hidroponik. Jurnal AGRIFOR, 16(1), 65-74.

Sarido, L., \& Junia. (2017b). Uji Pertumbuhan dan Hasil Tanaman Pakcoy (Brassica rapa L.) dengan Pemberian Pupuk Organik Cair pada Sistem Hidroponik. Jurnal AGRIFOR, 16(1), 65-74.

Siregar, M. (2017). Respon Pemberian Nutrisi AB-mix pada Sistem Tanam Hidroponik terhadap Pertumbuhan dan Produksi Tanaman Sawi (Brassica juncea). Journal of Animal Science and Agronomy Panca Budi, 2(2), 18-24.

Suhardiyanto, H. (2010). Teknologi Hidroponik untuk Budidaya Tanaman.

Swastika, S., Yulfida, A., \& Sumitro, Y. (2018).
Budidaya Sayuran Hidroponik (Fahroji (ed.)). Badan Penelitian Teknologi Pertanian.

Tama, A. W., \& Suprihati, S. (2020). Perakitan Pupuk Alternatif untuk Budidaya Sawi Pakcoy (Brassica rapa subsp. chinensis) dengan Sistem Hidroponik Rakit Apung. Jurnal Teknik Pertanian Lampung (Journal of Agricultural Engineering), 9(3), 163. https://doi.org/10.23960/jtep1.v9i3.163-170 
Lampiran

Lampiran 1. pH Larutan Semua Perlakuan di Pagi Hari dan Sore Hari

Pagi Sore

\begin{tabular}{|c|c|c|c|c|c|c|c|c|c|c|c|c|}
\hline 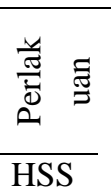 & $\begin{array}{c}\text { ABmix } \\
\text { A5ml/1 } \\
+ \\
\text { B5ml/l }\end{array}$ & $\begin{array}{l}\mathrm{POC} \\
2 \mathrm{ml} / 1\end{array}$ & $\begin{array}{l}\mathrm{POC} \\
4 \mathrm{ml} / 1\end{array}$ & $\begin{array}{l}\mathrm{POC} \\
6 \mathrm{ml} / 1\end{array}$ & $\begin{array}{l}\mathrm{POC} \\
8 \mathrm{ml} / 1\end{array}$ & $\begin{array}{c}\text { POC } \\
10 \mathrm{ml} / 1\end{array}$ & $\begin{array}{c}\mathrm{ABmix} \\
\mathrm{A} 5 \mathrm{ml} / \mathrm{l} \\
+ \\
\mathrm{B} 5 \mathrm{ml} / \mathrm{l}\end{array}$ & $\begin{array}{l}\mathrm{POC} \\
2 \mathrm{ml} / 1\end{array}$ & $\begin{array}{l}\text { POC } \\
4 \mathrm{ml} / 1\end{array}$ & $\begin{array}{l}\text { POC } \\
6 \mathrm{ml} / 1\end{array}$ & $\begin{array}{l}\text { POC } \\
8 \mathrm{ml} / 1\end{array}$ & $\begin{array}{c}\text { POC } \\
10 \mathrm{ml} / 1\end{array}$ \\
\hline 12 & 5,50 & 5,50 & 5,50 & 5,50 & 5,50 & 5,50 & 6,45 & 7,00 & 6,60 & 6,55 & 6,20 & 5,88 \\
\hline 13 & 5,50 & 7,23 & 7,20 & 6,98 & 7,10 & 6,58 & 5,40 & 7,13 & 7,10 & 6,88 & 7,00 & 6,48 \\
\hline 14 & 6,10 & 7,35 & 7,65 & 7,93 & 6,95 & 6,95 & 6,00 & 7,25 & 7,55 & 7,83 & 6,85 & 6,85 \\
\hline 15 & 5,93 & 6,83 & 7,68 & 7,60 & 7,28 & 7,30 & 6,45 & 7,23 & 7,73 & 8,00 & 7,48 & 7,63 \\
\hline 16 & 6,08 & 6,95 & 7,33 & 7,95 & 7,58 & 7,73 & 5,98 & 6,85 & 7,23 & 7,85 & 7,48 & 7,63 \\
\hline 17 & 5,88 & 6,75 & 7,13 & 7,75 & 7,38 & 7,53 & 6,05 & 6,80 & 6,90 & 7,60 & 6,88 & 7,38 \\
\hline 18 & 5,93 & 6,73 & 6,70 & 6,65 & 6,78 & 6,83 & 5,83 & 6,63 & 6,60 & 6,55 & 6,68 & 6,73 \\
\hline 19 & 6,18 & 6,30 & 6,53 & 6,65 & 6,53 & 6,30 & 5,78 & 6,20 & 5,98 & 6,30 & 6,18 & 6,20 \\
\hline 20 & 6,45 & 6,68 & 6,48 & 6,55 & 6,50 & 6,40 & 6,28 & 6,43 & 6,35 & 6,45 & 6,43 & 6,30 \\
\hline 21 & 6,58 & 6,78 & 6,70 & 6,70 & 6,68 & 6,53 & 6,48 & 6,68 & 6,60 & 6,60 & 6,58 & 6,43 \\
\hline 22 & 6,35 & 6,98 & 7,00 & 6,35 & 6,18 & 6,35 & 6,25 & 6,88 & 6,90 & 6,25 & 6,08 & 6,25 \\
\hline 23 & 6,60 & 7,03 & 6,90 & 6,85 & 6,78 & 6,63 & 6,50 & 6,93 & 6,80 & 6,75 & 6,68 & 6,53 \\
\hline 24 & 6,33 & 6,80 & 6,70 & 6,60 & 6,63 & 6,50 & 6,25 & 6,70 & 6,60 & 6,50 & 6,55 & 6,40 \\
\hline 25 & 6,50 & 6,73 & 6,40 & 6,40 & 6,38 & 6,28 & 6,40 & 6,63 & 6,30 & 6,30 & 6,28 & 6,18 \\
\hline 26 & 6,25 & 6,73 & 6,40 & 6,20 & 6,25 & 6,18 & 6,15 & 6,63 & 6,30 & 6,10 & 6,15 & 6,08 \\
\hline 27 & 6,55 & 6,80 & 6,55 & 6,25 & 6,35 & 6,18 & 6,45 & 6,70 & 6,45 & 6,15 & 6,25 & 6,08 \\
\hline 28 & 6,53 & 6,83 & 6,25 & 6,05 & 6,28 & $0,2 J$ & 6,4 & 6,73 & 6,15 & 5,95 & 6,18 & 6,13 \\
\hline 29 & 6,50 & 6,85 & 6,53 & 6,68 & 6,73 & 6,50 & 6,40 & 6,75 & 6,43 & 6,58 & 6,63 & 6,40 \\
\hline 30 & 6,95 & 6,70 & 6,00 & 6,25 & 6,25 & 5,85 & 6,50 & 5,88 & 6,03 & 5,88 & 5,93 & $\begin{array}{l}5,78 \\
\end{array}$ \\
\hline 31 & 7,20 & 6,53 & 6,20 & 6,15 & 6,93 & 6,73 & 6,38 & 6,38 & 6,03 & 5,98 & 6,73 & 6,68 \\
\hline 32 & 7,00 & 6,43 & 6,28 & 6,35 & 6,30 & 6,13 & 6,90 & 6,33 & 6,18 & 6,25 & 6,85 & 6,68 \\
\hline 33 & 7,38 & 6,38 & 6,73 & 6,55 & 6,80 & 6,90 & 7,28 & 6,30 & 6,63 & 6,45 & 6,68 & 6,50 \\
\hline 34 & 7,35 & 6,33 & 6,25 & 6,40 & 6,68 & 7,25 & 7,25 & 6,23 & 6,15 & 6,30 & 6,60 & 7,18 \\
\hline 35 & 7,15 & 6,00 & 6,43 & 6,20 & 7,05 & 7,10 & 7,05 & 5,90 & 6,33 & 6,10 & 6,90 & 7,00 \\
\hline 36 & 6,70 & 6,10 & 6,15 & 5,85 & 6,93 & 6,90 & 6,80 & 6,18 & 6,40 & 6,15 & 6,70 & 6,98 \\
\hline 37 & 7,75 & 6,40 & 6,30 & 6,30 & 6,68 & 7,13 & 7,65 & 6,30 & 6,20 & 6,20 & 6,58 & 7,03 \\
\hline 38 & 7,10 & 6,43 & 6,45 & 6,40 & 6,63 & 7,25 & 7,00 & 6,33 & 6,35 & 6,30 & 6,53 & 7,18 \\
\hline
\end{tabular}




\begin{tabular}{ccccccccccccc}
\hline 39 & 7,95 & 6,48 & 6,58 & 6,25 & 6,45 & 7,03 & 7,85 & 6,38 & 6,48 & 6,15 & 6,35 & 6,95 \\
\hline 40 & 8,15 & 6,58 & 7,08 & 6,53 & 6,75 & 7,20 & 8,05 & 6,48 & 6,98 & 6,43 & 6,65 & 6,63 \\
\hline 41 & 6,40 & 5,73 & 5,88 & 6,03 & 5,90 & 6,03 & 6,33 & 5,73 & 5,83 & 5,93 & 5,85 & 5,93 \\
\hline 42 & 7,83 & 7,23 & 7,33 & 7,43 & 7,35 & 7,43 & 6,83 & 7,13 & 7,23 & 7,33 & 7,25 & 7,33 \\
\hline 43 & 7,83 & 7,88 & 7,73 & 8,08 & 7,75 & 7,83 & \multicolumn{7}{c}{ PANEN } \\
\hline
\end{tabular}

